\title{
C - reactive protein Levels During Orthodontic Tooth Movement
}

\author{
${ }^{1}$ Stanley Mathew, ${ }^{2}$ Reena Ranjit Kumar, ${ }^{3}$ Aseem Sharma, \\ ${ }^{1}$ Private Consultant Orthodontist, \\ ${ }^{2}$ Professor and Head DJ Dental College UP, India \\ ${ }^{3}$ Senior Lecturer at Institute of Dental Sciences Jammu.
}

\section{Introduction}

Oral health can have a modulating or aetiological role in other systemic diseases (Mustapha et al \& Tonetti et al. 2007) (Parahitiyawa et al. 2009) As postulated by Danesh et al. 2004 oral stimulus causes systemic elevation of inflammatory marker Periodontal Tissue Inflammation: Mechanical stimulus orthodontic tooth movement causes - acute inflammatory reaction in periodontal tissues- results in bone resorption to accommodate movement of the tooth (Sandy et al., 1993). C-Reactive Protein - first inflammatory marker to be described. Marker of inflammation and tissue damage(Pepys and Baltz,1983). Noack et al.(2001) related periodontal status to circulating CRP and a relationship between the severity of periodontitis and circulating CRP. Few studies - investigating systemic inflammatory marker levels in response to periodontal inflammation caused by orthodontic tooth movement.

\section{The Systemic Spread of Oral Bacteria and Their Products}

Bacteraemia have been reported in several studies during orthodontic procedures of banding, debanding, and placement of separators (McLaughlin et al., 1996; Erverdi et al., 1999, 2000; Lucas et al., 2002). Bacteria and their endotoxins - capable of generating systemic and local host responses. Inflammatory markers are recognized as surrogate measures of inflammation, acting locally, and systemically. Therefore the objective of this study was to assess if there is a clinically significant rise in inflammatory marker levels in response to conventional orthodontic forces.

\section{Aim of The Study}

Comparison of systemic levels of C-reactive protein in subjects-

1). undergoing orthodontic tooth movement,

2). in periodontitis, and

3). in a control group

\section{Material And Method}

A sample size of 30 subjects were divided into 3 groups:

1) Group A(10 subjects)- Undergoing orthodontic treatment, using a fixed appliance

2) Group B(10 subjects)- with periodontitis

3) Group C(10 subjects)-with healthy periodontium(control group)

\section{Exclusion Criteria:}

Patients with persistent or recurrent upper respiratory tract infections, asthma and obesity were ineligible for the study.

\section{Inclusion Criteria:}

All orthodontic subjects were in the retraction phase of treatment.

Subjects with localised chronic periodontitis were chosen in the periodontitis group.

\section{Method}

Blood samples of the orthodontic subjects were drawn 1 week after activation of the appliance. $2 \mathrm{ml}$ blood samples were taken from the cubital vein of each subject,in all three groups. Samples were sent to a laboratory for testing of $\mathrm{C}$ Reactive protein levels. A quantitative analysis of the samples were done and CRP values of individual groups were noted.The CRP levels in each group were compared with other groups to assess the difference in levels the protein.

Laboratory Analysis: The laboratory protocol followed the instructions of the CRP Turbilatex kit. The blood samples collected in vial tubes were left to clot for 30 minutes. The tubes were then centrifuged at $2300 \mathrm{rpm}$ for 15 minutes to separate the serum 

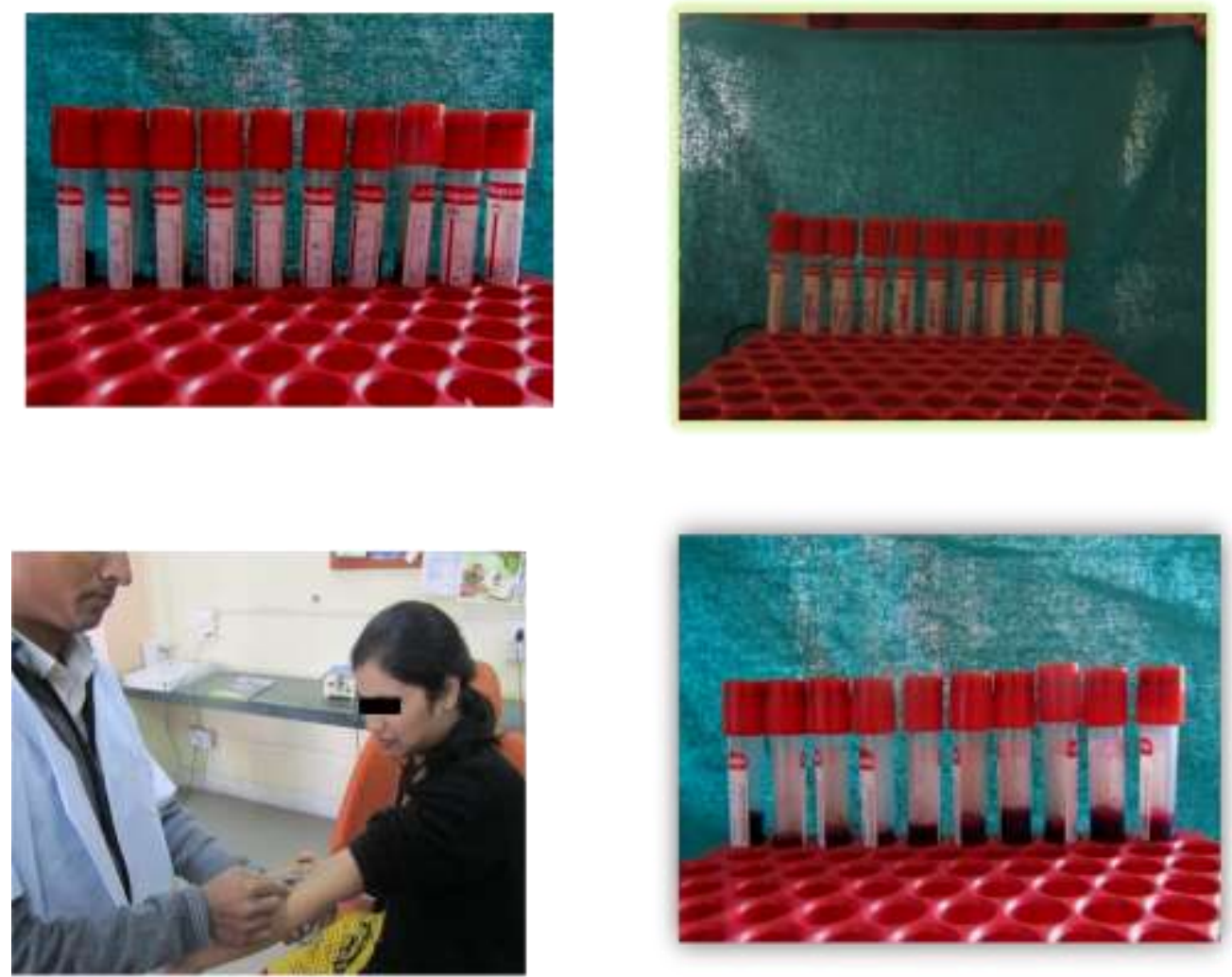

Samples were then analysed for CRP using quantitative test in a semi automatic ERBAMANNHEIM CHEM-5 PLUS, using the CRP Turbilatex kit.

The kit contains 3 reagents: R1-Buffer $(45 \mathrm{ml}), \mathrm{R} 2-$ Latex (5ml),R3-Calibrator $(0.5 \mathrm{ml})$
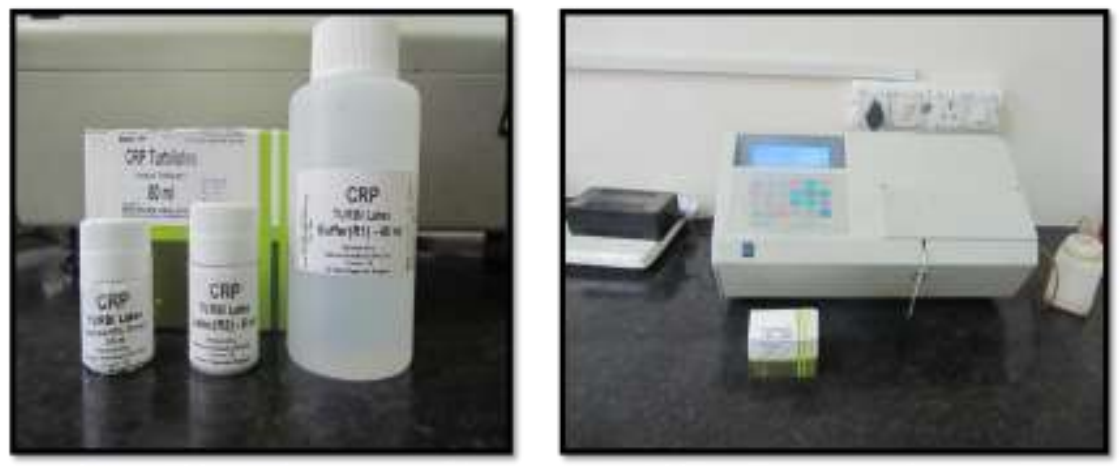


\section{Result}

The results of the study are summarised in the following tables.

Table 1: Shows the levels of C- reactive protein in each group:

\begin{tabular}{|l|l|l|}
\hline $\begin{array}{c}\text { CONTROL GROUP } \\
(\mathbf{m g} / \mathbf{L})\end{array}$ & $\begin{array}{c}\text { PERIODONTITIS } \\
(\mathbf{m g} / \mathbf{L})\end{array}$ & $\begin{array}{l}\text { During orthodontic tooth } \\
\text { movement(1week } \\
\text { activation)mg/L }\end{array}$ \\
\hline 0.62 & 1.56 & 0.47 \\
\hline 1.06 & 0.74 & 0.82 \\
\hline 0.46 & 2.65 & 1.53 \\
\hline 1.54 & 2.68 & 1.25 \\
\hline 0.82 & 0.92 & 0.56 \\
\hline 1.31 & 2.64 & 1.12 \\
\hline 0.76 & 1.45 & 0.35 \\
\hline 0.84 & 2.86 & 0.72 \\
\hline 0.28 & 1.84 & 1.21 \\
\hline 1.33 & 2.35 & 0.74 \\
\hline
\end{tabular}

\section{NORMAL CRP LEVEL $<6 \mathrm{mg} / \mathrm{L}$}

Table 2: Standard deviation and mean of each group

\begin{tabular}{|l|l|l|l|}
\hline & Control Group & Periodontitis & $\begin{array}{l}\text { During Orthodontic Tooth } \\
\text { Movement }\end{array}$ \\
\hline Standard Deviation & 0.4047 & 0.7762 & 0.3838 \\
\hline Mean & 0.9020 & 1.9690 & 0.8770 \\
\hline
\end{tabular}

Table-2

\begin{tabular}{|l|l|l|l|}
\hline & $\begin{array}{l}\text { Periodontitis group } \\
\text { v/s Control group }\end{array}$ & $\begin{array}{l}\text { Control group v/s } \\
\text { ortho group }\end{array}$ & $\begin{array}{l}\text { periodontitis group v/s } \\
\text { ortho group }\end{array}$ \\
\hline P value & $0.0025^{*}$ & 0.9586 & $0.0017^{*}$ \\
\hline \multicolumn{5}{|l}{ Table-3 }
\end{tabular}

Table 3 shows that there is a significant rise in CRP level of group with periodontitis $(\mathrm{p}<0.005)$ as compared to control group and group undergoing orthodontic tooth movement,and no significant change in control group v/s ortho group.

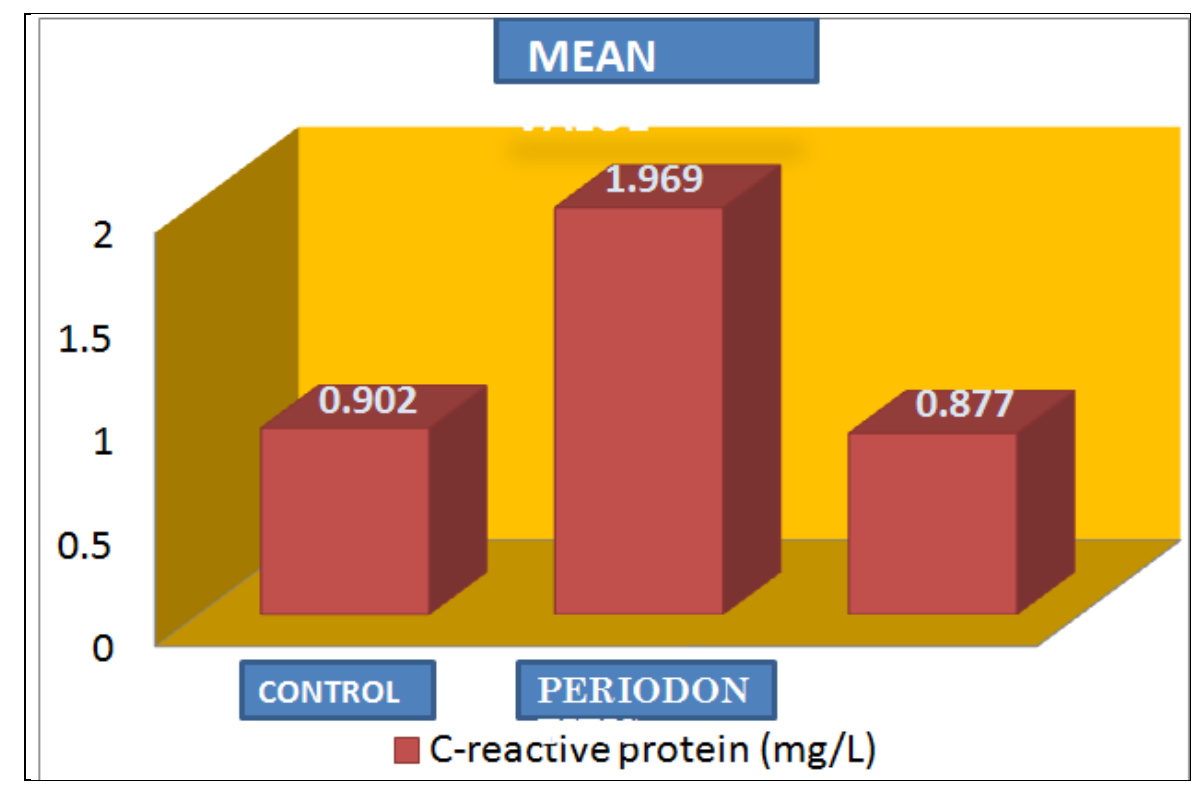

\section{Discussion}

CRP -biomarker of systemic inflammation and a marker of subsequent atherosclerosis and cardiovascular disease. Periodontal disease - known to induce systemic inflammation - partly mediated through acute phase reactants such as CRP. In adults, it is documented that elevated CRP is an independent predictor of DOI: 10.9790/0853-1603067073 www.iosrjournals.org 72 |Page 
adverse cardiovascular events (DeFerranti and Rifai 2007) Increasing levels of CRP are associated with up to a 3-fold increase in the risk of myocardial infarction and a 2-fold increase in the risk of ischaemic stroke (Ridker et al. 1997) Due to the commonality of elevated CRP in both periodontal and cardiovascular disease, oral problem can have a systemic effect. Bahekar et al.(2007) reported an increase in cardiovascular disease risk of between 1.14 and 1.59 times among patients with periodontal disease. This study was undertaken to assess whether the immune system was stimulated by orthodontic force. Stimulation caused either by local inflammatory damage of periodontal tissue having a systemic overlap or by systemic spread of bacteria or their toxins and products, or a combination of both these factors.

\section{Conclusion}

This study shows - no activation of the immune system (as indicated by normal levels inflammatory marker-CRP) during active therapy, and orthodontic treatment - immunologically safe. As it was a pilot study,more research needs to be done to check CRP levels at different time intervals during orthodontic treatment.

\section{References}

[1] Mustapha I Z, Debrey S, Oladubu M, Ugarte R 2007 Markers of systemic bacterial exposure in periodontal disease and cardiovascular disease risk: a systematic review and meta-analysis. Journal of Periodontology 78: 2289-2302

[2] Tonetti M S, D'Aiuto F, Nibali L 2007 Treatment of periodontitis and endothelial function. New England Journal of Medicine 356: 911-920

[3] Danesh J 2000 Low grade inflammation and coronary heart disease:prospective study and updated meta-analyses. British Medical Journal321: 199-204

[4] Danesh J, Wheeler J G, Hirschfield G M 2004 C-reactive protein and other circulating markers of inflammation in the prediction of coronary heartdisease. New England Journal of Medicine 350: 1387-1397

[5] Sandy J R, Farndale R W, Meikle M C 1993 Recent advances in understanding mechanically induced bone remodeling and theirrelevance to orthodontic theory and practice. American Journal ofOrthodontics and Dentofacial Orthopedics 103: 212-222

[6] Noack B, Genco R J, Trevisan M, GrossiS, Zambon J J, De Nardin E 2001 Periodontal infections contribute to elevated systemic Creactive proteinlevel. Journal of Periodontology 72: 1221-1227.

[7] McLaughlin J O, Coulter W A, Coffey A, Burden D J 1996 The incidence of bacteremia after orthodontic banding. American Journal of Orthodontics and Dentofacial Orthopedics 109: 639-644.

[8] Erverdi N, Biren S, Kadir T, Acar A 2000 Investigation of bacteremia following debanding. Angle Orthodontist 70: 11-14

[9] Erverdi N, Kadir T, Ozkan H, Acar A 1999 Investigation of bacteremia following orthodontic banding. American Journal of Orthodontics andDentofacial Orthopedics 116: 687-690

[10] Lucas V S, Omar J, Vieira A, Roberts G J 2002 The relationship between odontogenicbacteraemia and orthodontic treatment procedures.European Journal of Orthodontics 24: 293-301

[11] DeFerranti S D, Rifai N 2007 C-reactive protein: a nontraditional serum marker of cardiovascular risk. Cardiovascular Pathology 16: 14-21

[12] Ridker P M, Cushman M, Stampfer M J, Tracy R P, Hennekens C H 1997 Inflammation, aspirin, and the risk of cardiovascular disease inapparently healthy men. New England Journal of Medicine 336: 973-979

[13] Ridker P M, Hennekens C H, Buring J E, Rifai N 2000a C-reactive protein and other markers of inflammation in the prediction ofcardiovascular disease in women. New England Journal of Medicine342: 836-843

[14] Bahekar A A, Singh S, Saha S, Molnar J, Arora R 2007 The prevalence and incidence of coronary heart disease is significantly increased inperiodontitis: a meta-analysis. American Heart Journal 154: 830-837 